\title{
A Case Study on Misleading Celebrity Endorsements and its Impact on Consumer Behavior
}

\author{
Dr.P. Balasubramanian, Anjali V. Gopal and S. Reefana
}

\begin{abstract}
This study analyzes the effects of misleading celebrity endorsements on consumer's behavior in India. Celebrity endorsement is now a trend in India and is considered as one of the most powerful tools for product markets and brand building in this competitive era as stars are idolized and looked up in a country like India. The goal of every endorser is to convince the consumer that the said product will obtain the same result as the endorser, which plays a huge role in consumer's behavior. Previous studies have also showed that by making use of luminaries could upsurge the rate of acceptance among consumers towards a specific product. Misleading endorsements by these celebrities violate numerous rights of the consumers such as the right to information, choice, protection against unsafe goods and services as well as from unfair trade practices. To achieve the purpose, we choose to conduct a case study on Nestle's Maggi noodle brand to discuss, analyze and to draw conclusions. Finally, we have concluded that celebrities featuring in such commercials making false claims are accountable for their acts.
\end{abstract}

Keywords--- Misleading Celebrity Endorsements, Consumer's behavior, Rights of the Consumers, Nestle's Maggi Noodle, India.

\section{INTRODUCTION}

$\mathrm{I}_{\mathrm{N}}^{\mathrm{N}}$ NDIA is a country where stars are idolized and worshipped. Marketers use them so as to influence their existing or potential customers to succeed and reap huge profit. The manufacturers use various immoral methods like Concealment of facts, false claims and false testimonials thus violating several rights of the consumers. Celebrities who endorse the product should test, experiment and try the product to find out its quality. This has given rise to countless controversies in the Indian advertising industry. ${ }^{1}$

A. Motives behind Endorsements by Celebrities
1. Improving Credibility
2. Recognition of the brand
3. To refresh the brand/company image.
4. To boost the demand of the product

Dr.P. Balasubramanian, Assistant Professor, Department of Commerce and Management, Amrita School of Arts and Sciences, Kochi, India. E-mail:baladiwansapudur@gmail.com

Anjali V. Gopal, Student, Amrita School of Arts and Sciences, Kochi, India.E-mail:anjalihasbrain@gmail.com

S. Reefana, Student, Amrita School of Arts and Sciences, Kochi, India. E-mail:meerabebe@gmail.com

DOI: 10.9756/BIJIEMS.7464
5. To bring reliability on the product

6. To bring Retention of the product.

The favorite snack of many people is "Nestle's Maggi" which has always positioned their products with the attributes of health and quality. It adopted robust celebrity endorsements that has resulted in its advent as a brand and grow into market leader in the noodle segment with products MAGGI 2 Minute Noodles, MAGGI Extra delicious Chicken Noodles and Vegetable Atta Noodles, Oats Maggi catering to different consumer segments. According to the research conducted by the researcher Shamily Jaggi[15] more than 90 percent of the consumers preferred maggi noodles irrespective of the age before the controversy.

Recently it has been banned by the FSSAI (Food Safety and Standards Authority of India) because of problems linked with the product quality. The FSSAI acts as an agency of ministry of health and family of the country that is responsible for ensuring protection and promotion of health of the people by regulating and supervising the safety of the food. The notices were issued to many stars who had been endorsing Maggi noodles and the order for lodging FIR against it, has given rise to long legal debates regarding the liability of celebrities for endorsing the product.

\section{REVIEW OF LITERATURE}

The identification with an endorser then correlates with the buying behavior of the consumers (Ohanian, 1991). He also explains the effect of the endorser's expertise on the perceived credibility of a company that also affects the purchase intentions of consumers.

Atkins and Block, 1983 is of the view that consumers associate a brand with their favorite celebrity due to their attractiveness which makes the advertising more attractive.

According to Erdogan et al (2001), managers choose celebrities based on their characteristics for endorsing their product.

According to Till and Shimp (1998), celebrity endorsements shows a credible image of the company in terms of trust, expertise, objectiveness and persuasiveness.

According to Ellis (2000), the influence of celebrities, sportspersons and models can be seen typically in younger generations.

Pughazhendi et al. (2012), feels that advertisers make use of popular celebrities in their ads for promoting their product image. 
O'Mahony and Irish (1997) are of the opinion that celebrity endorsements can influence the consumers to make a recall, attention and purchase intentions.

\section{CONCEPTUAL FRAMEWORK}

\section{A. Celebrity Endorsement}

Celebrity endorsement is a form of brand campaign which involves a popular individual who uses their fame to help in promoting a product or a service. It helps a company to improve their credibility and boosts the demand of the product.

\section{B. Consumer Behavior}

Consumer behavior is the study of individuals, groups, or organizations and the processes they use to select, secure, use, and dispose of products, services, experiences, or ideas to satisfy needs and the impacts that these processes have on the consumer and society.

It is a decision process which individuals engage in for evaluating, acquiring, using or disposing of goods and services.

\section{DISCUSSION}

The International brand Maggi is owned by Nestle since 1947. The original company was founded in Switzerland in 1872 by Julius Maggi. Their products include instant soups, ketchups, stocks, sauces, seasonings and instant noodles.

Maggi was endorsed by the popular stars like: AmithabBachhan, PreethyZinta and Madhuri Dixit who has a strong influence over the consumer choices as their every word is taken as the ultimate truth.

The advertising campaign "Me and merimaggi- 2 minute meinkhushiyan" was endorsed by the most popular stars AmitabhBachhan and PreethyZinta was active 12 years ago, while Maggi Oats noodles was endorsed by Madhuri Dixit. In the past 68 years maggi has entered all most every Indians body without any age limitation as all were addicted to its flavor. It comes with a tag that says, "No added MSG" (monosodium glutamate) and the company also stated that they regularly monitored for lead in accredited laboratories.

Recently enough, the very famous global brand Nestle faced a controversy that out of 13 samples tested by FSSAI 10 samples where containing excessive lead (17.2ppm) than the permissible limit $(2.5 \mathrm{ppm})$ which is regarded as unsafe for health, its presence in blood in high levels may cause lead poisoning, which can cause severe mental and physical impairment in a person. It slows down development process, cause chest pain, nausea and learning disability in children.

They also face the charge of mislabeling with regard to monosodium glutamate (MSG) content on its packets. According to the Food Safety and Standards Rules, 2011, MSG is a "flavor enhancer" that is found to be harmful for our health. It is obligatory for companies to mention on the packaging if MSG has been added. This may adversely affect the brain, weakening of bones, and kidney failure. This may also increase the risk to pregnant women and children.
New Delhi government banned the sale of Maggi Noodles on 3rd June 2015, Gujarat Food Development Authority, Tamil Nadu, Uttarakhand and Jammu \& Kashmir banned this on 4th June 2015. On June 5th Andhra Pradesh and Assam government and on June 7th the Ministry of Health and Welfare of Karnataka banned Maggi.

Since these celebrities are leading a public life, they should have given due diligence while accepting its endorsements without checking it. They should have been aware that they have a greater individual and moral responsibility and their actions have wide social implications.

However, FSSAI states that any person who makes a false claim about the efficacy of the product or nutritional value of the product without providing any scientific justification would be violating the act. Bihar court had registered an FIR against the celebrities for endorsing maggi. But in reality, these laws does not affect these stars as they will always find a way out and such laws cannot indemnify the losses incurred by the consumers by consuming Maggi.

For example when Reebok launched its sports shoes EasyTone that claimed that the shoes toned calf muscles by $11 \%$, which was found to be a false claim. And the company faced legal charges of deceptive advertising, and Bipasha Basu, who endorsed those shoes, walked away with a payment and faced no consequences.

After the controversy and ban on Maggi noodles the sales have crashed by over 90 per cent fromRs. 350 crore a month to Rs. 30 crore a month. According to the study on Maggi crisis in the Time of new media $46 \%$ has changed with switching to other brands. This leads the consumer to shift their consumption towards the SunfeastYippie Noodles. Thus it became an opportunity to boost the sale of SunfeastYippie Noodles further by highlighting the quality and safety standards. At the end of 2015 Maggi noodles had a comeback and tried to get the attention of the consumer without celebrities and concentrated in getting back the trust of consumers. From this we understand that the consumers were influenced by the celebrities who endorsed this product but after the controversy they just ignored the product even after they comeback.

The celebrities should consider FSSAI certificate as a prerequisite to endorse it and they can also sought the assistance from Advertising Standards Council of India (ASCI), a self-regulatory voluntary organization of the advertising industry to verify whether the ad is in alignment with the ASCI code and laws of the country. They are responsible in this regard not only to sustain their reputation but also for ensuring the safety of the society. Thus the primary role of an ambassador being to create awareness among the customers about the product therefore they should not deceive them with wrong facts and figures. Most of the time, people buy certain products just because their favorite celebrities endorse it. So this shows that they have more accountability and responsibility on their part. 


\section{QUESTIONS FOR DISCUSSION}

A. Who are all the celebrities involved in endorsing this product?

B. What was the recent controversy charged against them?

C. On ethical grounds, should celebrities endorsing such brands be punished by law?

D. Change of Consumer behavior after the controversy.

E. How will these celebrities monitor the quality and safety of the products they endorse it?

\section{CONCLUSION}

Celebrities symbolize knowledge, belief and aspiration in the eyes of consumers. Researchers like Atkins \&Blocks, Till \&Shimp, Pughazhendy too opines that celebrity endorsement shows a credible image of the company in terms of trust, expertise, objectiveness $\&$ persuasiveness.

Their mass appeal to attract target customers earns them huge endorsement amount and the consumers are too preoccupied to give much thought, so they go to the stores and purchase it blindly. They have a notion that if a product is good enough for the star, it is good enough for them. Therefore, the influence of misleading celebrity endorsements on the consumer behavior plays an enormous role.

So celebrities have to possess a sense of moral and ethical responsibility while endorsing any product whether it is consumable or otherwise.

\section{REFERENCES}

[1] A. Arora and K. Sahu, "Celebrity endorsement and its effect on consumer behavior", International Journal of Retailing\&Rural Business Perspectives, Vol.3, No.2, Pp. 866-869.

[2] C. Atkins, J. Hocking and M. Block, "Media effects on the young teenage drinking:Does advertising make a difference?", Journal of Communication, Vol.34, No.2,Pp. 157-167, 1984.

[3] Chatterjee Pritha, "Controversy surrounding Maggi noodles", The Indian Express, 2015.

[4] K. Debevec and J.B. Kernan, "More Evidence on the effects of a presenter's attractiveness some cognitive, affective, and behavioral Consequences", Association for Consumer Research, Vol.11, Pp.127132.

[5] J. Ellis, Seeing things: Television in the age of uncertainty, I.B. Tauris \& Co. Ltd, (Desertion, graduate school southern Illinoisuniversity, London), 2000.

[6] B.Z. Erdogan, M.J. Baker and S. Tagg, "Selecting celebrity endorsers: The practitioner's perspective", Journal of Advertising Research, Vol. 41, No. 3,Pp. 39-48, 2001.

[7] H. Friedman and L. Friedman, "Endorser Effectiveness by Product Type", Journal of Advertising Research, Vol.19, No.5, Pp. 63-71, 1979.

[8] A.M. Jigeesh, "Brand ambassadors may be made liable for misleading ads", The Hindu Business line, 2016.

[9] R. Ohanian, "The impact of celebrity spokespersons' perceived image on intention to purchase", Journal of Advertising Research, Vol. 31, No. 1, Pp. 46-54, 1991.

[10] S. O'Mahoney and T. Meenaghan, "The impact of celebrity endorsements on Consumers", Irish Marketing Review, Vol. 10, No. 2, Pp. 15-24, 1998.

[11] A. Pughazhendi, R.N. Balamurugan and R. Sudharani, "Impact of celebrity Endorsement on advertisement in Various Media towards Selected Retail Outlets in Chennai City, India”, TMC Academic Journal. Vol. 6, No. 2, Pp. 32-43, 2012.

[12] M. Solomon, G. Bamossy and S. Askegaard, Consumer behaviour: A perspective, (2nd Edition), UK: Prentice Hall Europe, 2002.
[13] B.D. Till and T.A. Shimp, "Endorsers in advertising:The case of negative celebrity information", Journal of Advertising, Vol. 27, No. 1, Pp. 67-82, 1998.

[14] Celebrity endorsement April 12, 2016. Retrieved from http://2] www.businessdictionary.com/definition/celebrity-endorsement.html

[15] Shamily Jaggi, "Tradeoff of Advertising and Publicity: A Case Study On Maggi in PAN India", IOSR Journal of Business and Management (IOSR-JBM), Vol. 17, No. 8, Pp. 97-103, 2015.

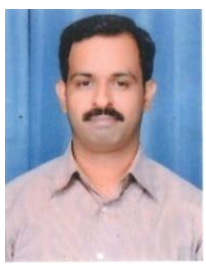

Dr.P. Balasubramanian, M.B.A. (Finance), M.Phil. (Management), M.Com. (Finance), Ph.D, Assistant professor, Amrita School of Arts and Sciences, Kochi. He was born on $7^{\text {th }}$ April 1983. He has eleven years of teaching experience. He has published two of his papers in Journal of Commerce and Management Thoughts and one paper in International Journal of Research in Commerce and Management.

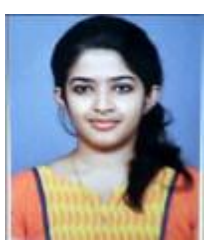

Anjali V. Gopal was born on $13^{\text {th }}$ May 1994 in Ernakulam district. She has completed her B.Com (Taxation) in Chinmaya vidyapeet, Ernakulam in the year 2015. Currently she is pursuing her second year M.com (Finance and systems) in Amrita School of Arts and Science, Kochi.

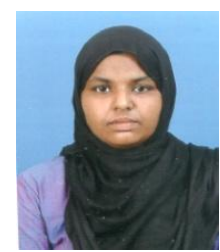

S. Reefana was born on $4^{\text {th }}$ December 1994 in Coimbatore district. She has completed her B.Com in PSGR Krishnammal College for women, Coimbatore in the year 2015. Currently she is pursuing her second year M.Com (Finance and systems) in Amrita School of Arts and Science, Kochi. 